\title{
PENGARUH FAKTOR PRIBADI TERHADAP KEPUTUSAN KONSUMEN BERKUNJUNG KE NEXTDOOR CAFE DI PALU
}

\author{
Dini Wahyuni \\ Prof. Dr. H. Syamsul Bachri, SE. M.Si \\ Program Studi S1 Manajemen Fakultas Ekonomi dan Bisnis Universitas Tadulako \\ email: diniwahyuni0806@yahoo.com; syamsulbachri09@gmail.com
}

\begin{abstract}
This study aims to determine whether there is an influence of personal factors consisting of age and stages of the life cycle, work, lifestyle, economic conditions, and personality and self-concept of consumer decisions to visit Nextdoor Cafe in Palu City. This type of research uses quantitative research methods. Data collection methods used were observation, interviews, and questionnaires. The population in this study is the visitors of Nextdoor Cafe. Sampling technique using accidental sampling with the number of informants as many as 60 samples. Retrieval of data by distributing questionnaires. The results showed that personal factors consisting of age and stages of the life cycle, work, lifestyle, economic conditions, as well as personality and self-concept partially and simultaneously influence consumer decisions to visit Nextdoor Cafe in Palu City.

Keywords: Age and Life Cycle stage, Work, Lifestyle, Economic Situation, Personality and Self Concepts
\end{abstract}

\begin{abstract}
Abstrak
Penelitian ini bertujuan untuk mengetahui apakah ada pengaruh faktor-faktor pribadi yang terdiri dari usia dan tahap siklus hidup, pekerjaan, gaya hidup, keadaan ekonomi, serta kepribadian dan konsep diri terhadap keputusan konsumen berkunjung ke Nextdoor Cafe di Kota Palu. Jenis penelitian ini menggunakan metode penelitian kuantitatif. Metode pengumpulan data yang digunakan adalah observasi, wawancara, dan kuesioner. Populasi dalam penelitian adalah pengunjung Nextdoor Cafe. Teknik penarikan sampel menggunakan accidental sampling dengan jumlah informan sebanyak 60 sampel. Pengambilan data dengan cara membagikan kuisioner. Hasil penelitian menunjukan bahwa faktor pribadi yang terdiri dari usia dan tahap siklus hidup, pekerjaan, gaya hidup, keadaan ekonomi, serta kepribadian dan konsep diri berpengaruh secara parsial dan secara simultan terhadap keputusan konsumen berkunjung ke Nextdoor Cafe di Kota Palu.
\end{abstract}

Kata kunci: Usia dan Tahap Siklus Hidup, Pekerjaan, Gaya Hidup, Keadaan Ekonomi, Kepribadian dan Konsep Diri

\section{PENDAHULUAN}

Perilaku konsumen dalam mengambil keputusan dipengaruhi oleh beberapa faktor, antara lain faktor budaya, sosial, pribadi dan psikologis. Dalam penelitian ini lebih berfokus pada faktor pribadi. Faktor pribadi dapat dilihat dari beberapa aspek meliputi usia dan tahap siklus hidup, yaitu keadaan yang menggambarkan riwayat manusia sejak awal tahun kehidupan sampai dengan akhir kehidupannya, setelah itu pekerjaan yaitu jenis mata pencarian yang menjadi sumber penghasilan seseorang, selanjutnya faktor pribadi juga ditinjau dari gaya hidup, yaitu pola hidup seseorang yang diekspresikan dalam aktifitas, minat dan opini, setelah itu keadaan ekonomi yaitu tingkat kesejahteraan seseorang dalam kehidupannya yang dilihat dari penghasilannya, dan yang terakhir kepribadian dan konsep diri yaitu perilaku yang konsisten dan bertahan lama yang ada pada diri seseorang dan dinilai memiliki pengaruh terhadap perilaku konsumen dalam mengambil keputusan.

Usaha Cafe \& Resto merupakan usaha yang saat ini banyak ditekuni oleh para pengusaha di Kota Palu salah satunya Nextdoor Cafe, merupakan usaha yang bergelut dalam bidang kuliner. Usaha ini dinilai dapat memberikan keuntungan karena merupakan bidang usaha yang menjadi salah satu kebutuhan bagi para konsumen. Perkembangan zaman dan trend yang terjadi pada masyarakat saat ini mempengaruhi perilaku konsumen, dilihat dari pola hidup masyarakat di Kota 
Palu yang ingin mencoba segala sesuatu yang baru dan dalam kalangan tertentu cenderung menghabiskan waktu di luar baik pada waktu luang saat bekerja maupun hanya untuk bersantai dengan teman atau rekan kerja. Selain menjadi tempat pilihan konsumen untuk berwisata kuliner, Nextdoor Cafe juga sering kali dijadikan tempat untuk rapat atau meeting oleh berbagai organisasi atau pengusaha dan tempat para muda-mudi berkumpul seperti mahasiswa dan pelajar yang ingin membuat tugas atau hanya sekedar bersantai bersama teman-temannya (Towoliu dan Tumbuan, 2017).

Untuk itu perlu dilakukan penelitian untuk mengetahui lebih dalam seperti apa variabel faktor pribadi yang terdiri dari usia dan tahap siklus hidup, pekerjaan, gaya hidup, keadaan ekonomi, kepribadian dan konsep diri pada Nextdoor Cafe di Kota Palu mampu menimbulkan keputusan pembelian konsumen.

\section{KAJIAN LITERATURE}

\section{Manajemen Pemasaran}

Suparyanto dan Rosad (2015:1) mengatakan manajemen pemasaran merupakan proses penganalisaan, perencanaan, pengaturan, dan pengengelolaan semua program termasuk pengonsepan, ketetapan harga, distribusi dan promosi produk yang dirancang untuk menjaga pertukaran dengan pasar sasaran demi tujuan suatu perusahaan.

Assauri (2013:12) mendefinisikan manajemen pemasaran merupakan cara pencapaian tujuan perusahaan jangka panjang dengan melakukan kegiatan penganalisaan, perencanaan, pelaksanaan dan pengendalian program disusun dalam pembentukan, pembangunan, dan pemeliharaan keuntungan dari pertukaran melalui sasaran pasar. Sedangkan Kotler dan Keller (2016:27) mendefinisikan "marketing management as the art and science of choosing target markets and getting, keeping, and growing customers through creating, delivering, and communicating superior customer value", dengan artian manajemen pemasaran yaitu seni dan ilmu memilih pasar sasaran dan mendapatkan, mempertahankan, serta meningkatkan jumlah pelanggan demi menciptakan, menghantarkan, dan mengkomunikasikan nilai pelanggan yang unggul.

\section{Perilaku Konsumen}

Sunyoto (2015:4) mendefinisikan perilaku konsumen sebagai upaya yang dilakukan seorang, kelompok, atau organisasi berhubungan dengan proses pengambilan keputusan untuk mendapatkan, menggunakan barang atau jasa ekonomis dipengaruhi lingkungan. Sedangkan Kotler dan Amstrong (2013:158) mengartikan perilaku konsumen yaitu perilaku pembelian konsumen akhir, perorangan dan rumah tangga yang membeli barang atau jasa untuk konsumsi pribadi. Semua konsumen akhir ini bergabung menyusun pasar konsumen. Pengertian lain perilaku konsumen yaitu "consumer behaviors is the study of how individuals, groups, and organizations select, buy, use, and dispose of goods, services, ideas, or experiences to satisfy their needs and wants", yang artinya perilaku konsumen yaitu studi tentang bagaimana individu, kelompok, dan organisasi memilih, membeli, menggunakan, dan membuang barang, layanan, ide, atau pengalaman demi memenuhi kebutuhan dan keinginan mereka, Kotler dan Keller (2016:112)

\section{Proses Keputusan Pembelian}

Kotler dan Keller (2016:187) mengatakan proses keputusan pembelian adalah proses konsumen melewati lima tahap, meliputi pengenalan masalah, pencarian informasi, evaluasi alternatif, keputusan pembelian, dan perilaku pasca pembelian, yang dimulai jauh sebelum pembelian aktual dilakukan dan memiliki dampak yang lama setelah itu.

Perilaku konsumen dalam melakukan pembelian sangat dipengaruhi oleh beberapa faktor. Terdapat tiga faktor yang dapat mempengaruhi perilaku konsumen dalam pembelian suatu produk. 
Vol. 6, No.3, September 2020, 261-271

Faktor-faktor ini memberi pengaruh yang cukup signifikan terhadap konsumen dalam memilih produk yaitu faktor budaya, faktor sosial, faktor dan pribadi, Kotler dan Keller (2016:179-184).

Faktor pribadi diartikan sebagai karakteristik seseorang yang berbeda dengan orang lain dan menyebabkan tanggapan yang relatif konsisten dan bertahan lama terhadap lingkungan, Kotler dan Keller (2016:206). Faktor pribadi tersebut meliputi usia dan tahap siklus hidup, pekerjaan, gaya hidup, keadaan ekonomi, serta kepribadian dn konsep diri.

1. Usia dan Tahap Siklus Hidup

Yaitu seperti apa tahap kehidupan seseorang sejak bayi, anak-anak, remaja, dewasa, hingga menjadi orang tua atau lansia. Menurut Kotler dan Keller (2016:206), orang-orang mengubah barang atau jasa yang mereka beli sepanjang kehidupan mereka.

2. Pekerjaan

Kotler dan Keller (2016:207) mengatakan pekerjaan seseorang berpengaruh pada barang atau jasa yang dibelinya. Pemasar berupaya mengidentifikasi kelompok-kelompok berdasarkan pekerjaan yang memiliki minat di atas rata-rata dalam produk dan jasa.

3. Gaya Hidup

Kotler dan Keller (2016:207) mengatakan gaya hidup yaitu pola kehidupan seseorang seperti yang diperlihatkannya dengan aktifitas, minat, dan opininya. Aktifitas yang dimaksud seperti pekerjaan, hobi, berbelanja, olahraga, dan kegiatan sosial. Kemudian minat yang meliputi makanan, mode, keluarga, dan rekreasi.

4. Keadaan Ekonomi

Kotler dan Keller (2016:208), keadaan ekonomi seseorang akan berpengaruh pada pilihan produk konsumen. Jika indikator-indikator ekonomi mengarah pada resesi, pemasar bisa mengambil langkah-langkah untuk mendesain ulang, memposisikan dan menetapkan kembali harga produk mereka dengan cepat.

5. Kepribadian dan Konsep Diri

Kotler dan Keller (2016:211), mengatakan kepribadian yaitu karakteristik psikologis unik seseorang yang menghasilkan tanggapan-tanggapan yang relatif konsisten dan menetap tarhadon linokunoannug. Sedangkan konsep diri adalah bahwa apa yang dimiliki seseorang Faktor Pribadi (X) mencerminkan identitas mereka.

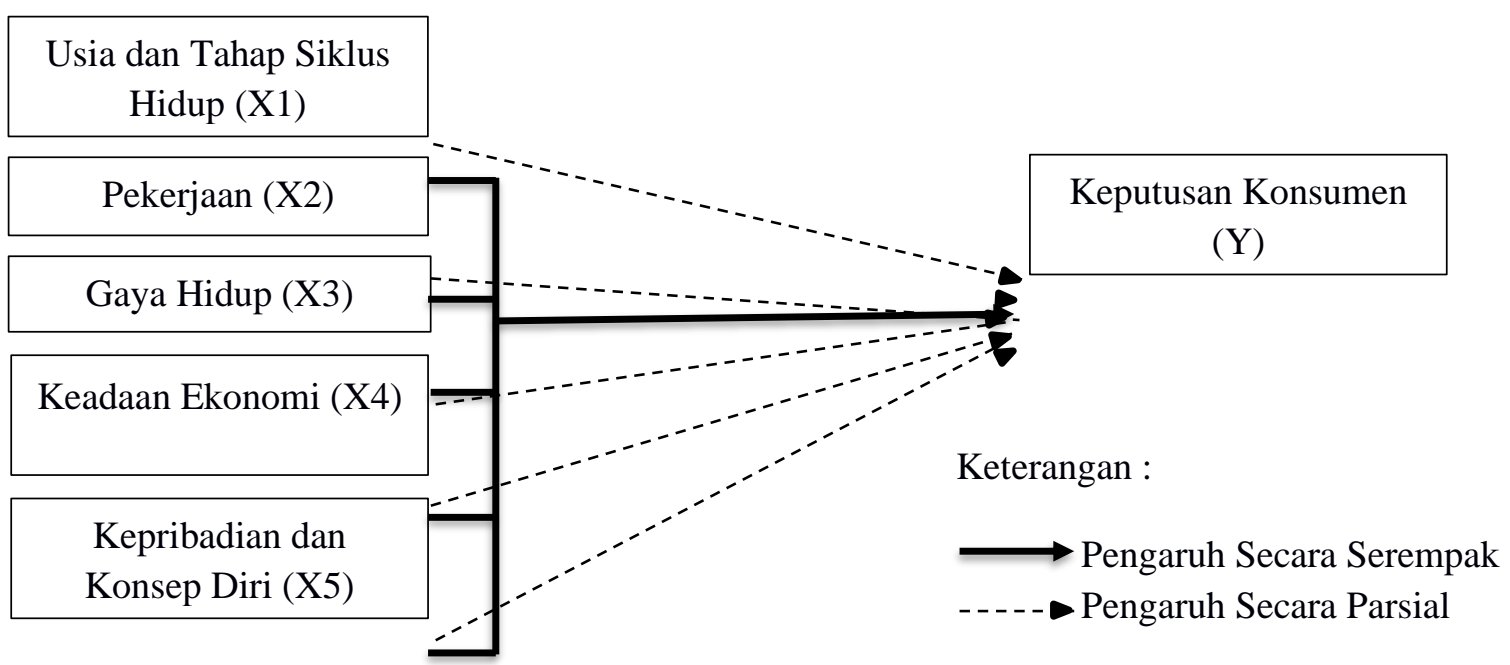

Sumber : Kotler dan Keller, 2016:206

Gambar 1. Kerangka Pemikiran 


\section{METODE PENELITIAN}

Pada penelitian ini digunakan tipe deskriptif dan kausal. Menurut Sugiyono (2016) penelitian deskriptif yaitu penelitian yang menggambarkan, menjelaskan variabel-variabel penelitian atau menganalisis suatu hasil penelitian. Menurut Ferdinand (2014) penelitian kausal yaitu ingin mencari penjelasan dan menganalisis hubungan sebab-akibat (cause-effect) antarbeberapa variabel. Penelitian tipe kausal memperlihatkan keterkaitan hubungan dan pengaruh faktor pribadi yang terdiri dari usia dan tahap siklus hidup, pekerjaan, gaya hidup, keadaan ekonomi, serta kepribadian dan konsep diri terhadap konsumen yang berkunjung ke Nextdoor Cafe di Kota Palu. Sedangkan deskriptif adalah penelitian yang memberikan penggambaran dari keterkaitan hubungan dan pengaruh faktor pribadi terhadap keputusan konsumen berkunjung ke Nextdoor Cafe di Kota Palu.

Menurut Sugiyono (2016) objek penelitian adalah segala sesuatu yang berbentuk apa saja yang ditetapkan oleh peneliti untuk dipelajari mengenai informasi tentang hal tersebut, kemudian ditarik kesimpulannya. Berdasarkan pemahaman tersebut, dalam konteks penelitian ini yang dimaksud objek penelitian adalah "Pengaruh Faktor Pribadi terhadap Keputusan Konsumen Berkunjung ke Nextdoor Cafe di Kota Palu".

Subjek penelitian adalah benda, hal, atau orang, tempat data untuk variabel penelitian. Dalam penelitian ini yang menjadi subjek dari penelitian ini adalah konsumen Nextdoor Cafe di Kota Palu.

Populasi pada penelitian ini yaitu seluruh konsumen yang berkunjung ke Nextdoor Cafe di Kota Palu. Teknik pengumpulan data yang digunakan dalam penelitian ini adalah sebagai berikut :

1. Observasi, yaitu peneliti melakukan pengamatan langsung dalam pengumpulan data di lokasi penelitian yaitu Nextdoor Cafe.

2. Wawancara, yaitu peneliti melakukan pengumpulan data melalui wawancara langsung terkait data yang dibutuhkan kepada pengelola Nextdoor Cafe.

3. Kuesioner, yaitu peneliti melakukan pengumpulan data secara tertutup melalui beberapa daftar pertanyaan yang disusun secara tertulis dan diajukan kepada responden yang berkunjung ke Nextdoor Cafe.

Teknik penarikan sampel yang digunakan dalam penelitian ini adalah accidental sampling, yang menurut Sugiyono (2016:60) merupakan teknik penentuan sampel berdasarkan kebetulan, artinya siapa saja yang kebetulan bertemu dengan peneliti dan dapat digunakan sebagai sampel. Penelitian ini dilakukan selama kurang lebih 2 minggu dengan menyebarkan kuesioner kepada 60 responden di Nextdoor Cafe.

Besarnya sampel yang akan diambil, peneliti merujuk pada pendapat Roscoe dalam buku Research Methods For Business (1982:253) yang menyatakan jika pada suatu penelitian akan melakukan analisis dengan multivariate (kolerasi atau regresi ganda misalnya), maka jumlah anggota sampel minimal 10 kali dari jumlah variabel yang diteliti (variabel independen+variabel dependen). Jumlah variabel dalam penelitian ini adalah 6 yang terdiri dari variabel independen (usia dan tahap siklus hidup, pekerjaan, gaya hidup, keadaan ekomnomi, kepribadian dan konsep diri) dan variabel dependen (keputusan pembelian konsumen).

Skala pengukuran dalam penelitian ini akan diukur menggunakan skala likert. Pengujian instrumen dalam penelitian ini dilakukan di Nextdoor Cafe dengan melakukan pra-penelitian kepada 30 responden.

Pengujian validitas menurut Sugiyono (2016:218) menunjukkan derajat ketepatan antara data sesungguhnya terjadi pada objek dengan data yang dikumpulkan peneliti untuk mencari validitas sebuah item, kita mengkorelasikan skor item dengan total item-item tersebut. Sugiyono (2016:218) menyatakan bahwa item yang mempunyai korelasi positif dengan kriterium (skor total) serta korelasi tinggi, syarat minimum yang dapat dipenuhi adalah $0,3(\mathrm{r} \geq 0,3)$, maka instrumen atau kuesioner tersebut dinyatakan valid. 
Vol. 6, No.3, September 2020, 261-271

Uji reliabilitas adalah suatu angka indeks yang menunjukkan konsistensi suatu alat pengukur dalam mengukur gejala yang sama jika digunakan berulang kali, artinya uji reliabilitas digunakan untuk memastikan apakah kuesioner penelitian yang akan dipergunakan untuk mengumpulkan data variabel penelitian reliabel atau tidak. Kuesioner dikatakan reliabel jika kuesioner tersebut dilakukan pengukuran ulang, maka akan mendapatkan hasil yang sama. Menurut Sugiyono (2016:220), suatu instrumen dinyatakan reliabel apabila koefisien reliabilitas minimal $0,6(\alpha \geq 0,6)$.

Analisis kuantitatif dengan menggunakan angka-angka statistik melalui penggunaan alat analisis statistik parametrik Regresi Linear Berganda (Multiple Regression Analysis). Metode ini digunakan untuk mengukur dan menganalisis besarnya hubungan dan pengaruh faktor pribadi yang meliputi usia dan tahap siklus hidup, pekerjaan, gaya hidup, keadaan ekonomi, serta kepribadian dan konsep diri terhadap keputusan konsumen berkunjung ke Nextdoor Cafe di Kota Palu. Persamaan regresi linear berganda merupakan persamaan regresi dengan menggunakan dua atau lebih variabel independen. Bentuk alat analisis statistik regresi linear berganda secara matematis dapat dijabarkan sebagai berikut:

$\mathrm{Y}=\mathrm{a}+\mathrm{b} 1 \mathrm{X} 1+\mathrm{b} 2 \mathrm{X} 2+\mathrm{b} 3 \mathrm{X} 3+\mathrm{b} 4 \mathrm{X} 4+\mathrm{b} 5 \mathrm{X} 5 \ldots \mathrm{e}$

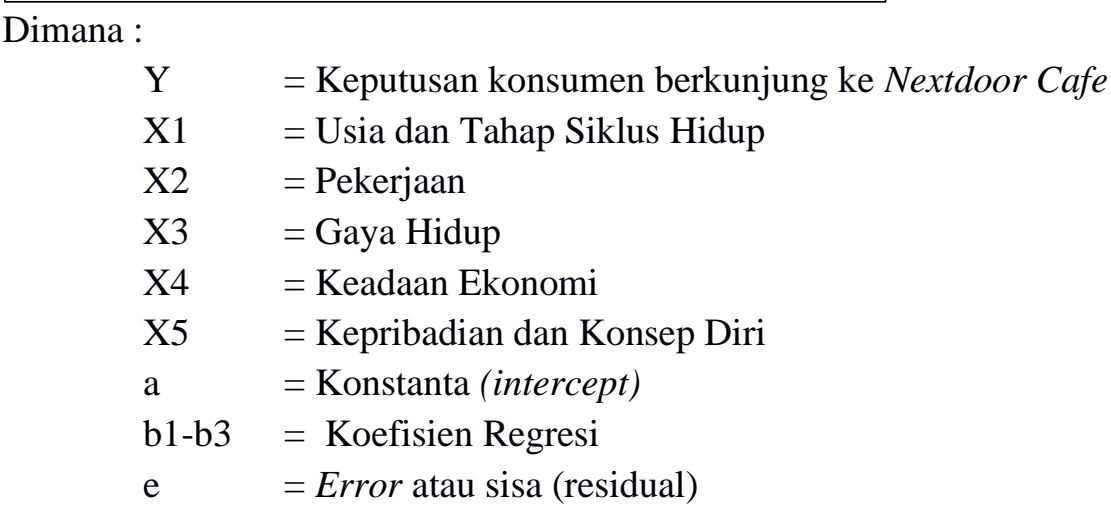

\section{HASIL DAN PEMBAHASAN}

Kuesioner yang disebarkan dalam penelitian ini berjumlah 60 dengan subjek penelitiannya adalah responden yang berkunjung dan melakukan pembelian di Nextdoor Cafe dengan melakukan penelitian selama kurang lebih 2 minggu.

Penelitian ini menggunakan analisis regresi linear berganda dengan tujuan untuk menguji variabel faktor pribadi terhadap keputusan konsumen berkunjung ke Nextdoor Cafe di Kota Palu dengan menggunakan bantuan software SPSS versi 22. Untuk lebih jelasnya, hasil analisis regresi linear berganda dapat dilihat pada Tabel 2 berikut :

Tabel 2. Hasil Uji Analisis Regresi Linear Berganda

\begin{tabular}{cccccc}
\hline \multicolumn{7}{c}{ Variabel Dependen $(\mathrm{Y})=$ Keputusan Konsumen } \\
\hline Variabel Independen (X) & \multicolumn{2}{c}{$\begin{array}{c}\text { Unstandardized } \\
\text { Coefficient }\end{array}$} & $\begin{array}{c}\text { Standardized } \\
\text { Coefficient } \\
\text { Beta }\end{array}$ & t & Sig. \\
& $\mathrm{B}$ & Std. Eror & Beta & & \\
\hline (Constant) & 1,572 & 2,576 & & 3,870 & 0,000 \\
Usia dan Tahap Siklus Hidup & 0,035 & 0,121 & 0,036 & 2,291 & 0,002 \\
Pekerjaan & 0,048 & 0,137 & 0,051 & 2,346 & 0,031 \\
Gaya Hidup & 0,445 & 0,202 & 0,331 & 2,198 & 0,032 \\
Keadaan Ekonomi & 0,188 & 0,153 & 0,177 & 2,227 & 0,025 \\
Kepribadian dan Konsep Diri & 0,201 & 0,160 & 0,173 & 2,255 & 0,015 \\
\hline
\end{tabular}


Vol. 6, No.3, September 2020, 261-271

$\begin{array}{llllll}\text { Multiple R } & =0,708 & \text { Sig. F }=000 & \mathrm{~F}_{\text {tabel }}=2,38 \\ \text { R Square } & =0,501 & \mathrm{~F}_{\text {hitung }}=4,178 & \mathrm{t}_{\text {tabel }}=2,004\end{array}$

Adjusted R Square $=0,479$

Sumber : Data, diolah (2019).

Berdasarkan tabel tersebut dapat diketahui hasil uji hipotesis pertama $\left(\mathrm{H}_{1}\right)$ digunakan untuk mengetahui apakah usia dan tahap siklus hidup, pekerjaan, gaya hidup, keadaan ekonomi, serta kepribadian dan konsep diri secara serempak berpengaruh signifikan terhadap keputusan konsumen berkunjung ke Nextdoor Cafe di Kota Palu. Berdasarkan Tabel 2, diperoleh nilai signifikansi F yaitu 0,000 . Artinya, nilai tersebut lebih kecil dari nilai yang disyaratkan yaitu $\alpha=0,05$ dengan tingkat kepercayaan $95 \%$. Dengan demikian, dapat dinyatakan bahwa variabel faktor pribadi yang meliputi usia dan tahap siklus hidup, pekerjaan, gaya hidup, keadaan ekonomi, serta kepribadian dan konsep diri secara serempak berpengaruh signifikan terhadap keputusan konsumen berkunjung ke Nextdoor Cafe di Kota Palu.

Hasil pengujian hipotesis kedua $\left(\mathrm{H}_{2}\right)$ dipakai untuk mengetahui apakah usia dan tahap siklus hidup $\left(\mathrm{X}_{1}\right)$ berpengaruh signifikan terhadap keputusan konsumen berkunjung ke Nextdoor Cafe di Kota Palu. Berdasarkan Tabel 2, menunjukkan bahwa variabel usia dan tahap siklus hidup $\left(\mathrm{X}_{1}\right)$ memiliki pengaruh signifikan sebesar 0,002. Artinya, nilai tersebut < (kurang dari) taraf yang disyaratkan yaitu $\propto=0,05$. Oleh karena itu, disimpulkan bahwa usia dan tahap siklus hidup berpengaruh signifikan terhadap keputusan konsumen berkunjung ke Nextdoor Cafe di Kota Palu.

Hasil pengujian hipotesis ketiga $\left(\mathrm{H}_{3}\right)$ digunakan untuk mengetahui apakah pekerjaan $\left(\mathrm{X}_{2}\right)$ berpengaruh signifikan terhadap keputusan konsumen berkunjung ke Nextdoor Cafe di Kota Palu. Berdasarkan Tabel 2, menunjukkan bahwa variabel pekerjaan $\left(\mathrm{X}_{2}\right)$ memiliki pengaruh signifikan sebesar 0,031 . Artinya, nilai tersebut $<$ (kurang dari) taraf yang disyaratkan yaitu $\propto=0,05$. Oleh karena itu, bisa disimpulkan bahwa pekerjaan berpengaruh signifikan terhadap keputusan konsumen berkunjung ke Nextdoor Cafe di Kota Palu.

Hasil pengujian hipotesis keempat $\left(\mathrm{H}_{4}\right)$ digunakan untuk mengetahui apakah gaya hidup $\left(\mathrm{X}_{3}\right)$ berpengaruh signifikan terhadap keputusan konsumen berkunjung ke Nextdoor Cafe di Kota Palu. Berdasarkan Tabel 2, menunjukkan bahwa variabel gaya hidup $\left(\mathrm{X}_{3}\right)$ memiliki pengaruh signifikan sebesar 0,032 . Artinya, nilai tersebut < (kurang dari) taraf yang disyaratkan yaitu $\propto=0,05$. Oleh karena itu, disimpulkan bahwa gaya hidup berpengaruh signifikan terhadap keputusan konsumen berkunjung ke Nextdoor Cafe di Kota Palu.

Hasil pengujian hipotesis kelima $\left(\mathrm{H}_{5}\right)$ digunakan untuk mengetahui apakah keadaan ekonomi $\left(\mathrm{X}_{4}\right)$ berpengaruh signifikan terhadap keputusan konsumen berkunjung ke Nextdoor Cafe di Kota Palu. Berdasarkan Tabel 2, menunjukkan bahwa variabel keadaan ekonomi $\left(\mathrm{X}_{4}\right)$ memiliki pengaruh signifikan sebesar 0,025 . Artinya, nilai tersebut < (kurang dari) taraf yang disyaratkan yaitu $\propto=$ 0,05. Oleh karena itu, disimpulkan bahwa keadaan ekonomi berpengaruh signifikan terhadap keputusan konsumen berkunjung ke Nextdoor Cafe di Kota Palu.

Hasil pengujian hipotesis keenam $\left(\mathrm{H}_{6}\right)$ digunakan untuk mengetahui apakah kepribadian dan konsep diri $\left(\mathrm{X}_{5}\right)$ berpengaruh signifikan terhadap keputusan konsumen berkunjung ke Nextdoor Cafe di Kota Palu. Berdasarkan Tabel 2, menunjukkan bahwa variabel kepribadian dan konsep diri $\left(\mathrm{X}_{5}\right)$ memiliki pengaruh signifikan sebesar 0,015. Artinya, nilai tersebut $<$ (kurang dari) taraf yang disyaratkan yaitu $\propto=0,05$. Oleh karena itu, dapat disimpulkan bahwa kepribadian dan konsep diri berpengaruh signifikan terhadap keputusan konsumen berkunjung ke Nextdoor Cafe di Kota Palu.

\section{Pembahasan}

\section{Pengujian Secara Serempak (Uji f)}

Berdasarkan Tabel 2, dapat dilihat nilai keofisien korelasi (Multiple $R$ ) sebesar 0,708, memberikan makna bahwa hubungan (korelasi) positif antara kelima variabel independen yang 
meliputi usia dan tahap siklus hidup, pekerjaan, gaya hidup, keadaan ekonomi, serta kepribadian dan konsep diri terhadap keputusan konsumen berkunjung ke Nextdoor Cafe di Kota Palu.

Pengujian hipotesis secara serempak diperoleh nilai $\mathrm{F}_{\text {hitung }}$ sebesar 4,178 > (lebih dari) nilai $\mathrm{F}_{\text {tabel }}$ sebesar 2,38 atau nilai probabilitinya sebesar $0,000<$ (kurang dari) nilai $\alpha=0,05$ pada tingkat kepercayaan 95\%. Maka dapat diketahui bahwa secara serempak variabel independen yang meliputi usia dan tahap siklus hidup, pekerjaan, gaya hidup, keadaan ekonomi, serta kepribadian dan konsep diri berpengaruh signifikan terhadap keputusan konsumen berkunjung ke Nextdoor Cafe di Kota Palu.

Kesimpulan untuk hipotesis pertama dalam penelitian ini adalah menolak $\mathrm{H}_{0}$ dan menerima $\mathrm{H}_{\mathrm{i}}$. Artinya hipotesis pertama penelitian secara ilmiah dapat dibuktikan kebenarannya. Hal ini dapat dilihat dari pengaruh hasil uji determinasi $R$ Square sebesar 0,501. Nilai tersebut dapat diartikan bahwa faktor pribadi yang meliputi usia dan tahap siklus hidup, pekerjaan, gaya hidup, keadaan ekonomi, serta kepribadian dan konsep diri mempunyai konstribusi secara bersama-sama sebesar 50,1\% terhadap variabel terikat yaitu keputusan konsumen pada Nextdoor Cafe di Kota Palu. Sedangkan sisanya $(100 \%-50,1 \%=49,9 \%)$, dipengaruhi oleh variabel lain yang tidak diteliti dalam penelitian ini.

Hal ini sejalan dengan penelitian yang dilakukan oleh Hakimi (2015), yang menunjukkan bahwa faktor pribadi yang meliputi usia dan tahap siklus hidup, pekerjaan, gaya hidup, keadaan ekonomi, serta kepribadian dan konsep diri berpengaruh signifikan terhadap keputusan konsumen.

\section{Pengujian Secara Parsial (Uji t)}

\section{Pengaruh Usia dan Tahap Siklus Hidup terhadap Keputusan Konsumen}

Berdasarkan Tabel 2, dapat dilihat nilai koefisien regresi varibel usia dan tahap siklus hidup $\left(\mathrm{X}_{1}\right)$ sebesar 0,035. Dapat diartikan bahwa usia dan tahap siklus hidup memberikan hubungan positif pada keputusan konsumen berkunjung ke Nextdoor Cafe di Kota Palu, dengan nilai koefisien regresi sebesar 0,035. Hal ini memberi makna kontribusi usia dan tahap siklus hidup $\left(\mathrm{X}_{1}\right)$ terhadap keputusan konsumen berkunjung ke Nextdoor Cafe di Kota Palu sebesar 3,5\%.

Pengujian hipotesis secara parsial diperoleh nilai $\mathrm{t}_{\text {hitung }}$ usia dan tahap siklus hidup $\left(\mathrm{X}_{1}\right)$ sebesar 2,291 > (lebih dari) nilai $t_{\text {tabel }}$ sebesar 2,004 atau nilai probabilitinya sebesar 0,002 < (kurang dari) nilai $\alpha=0,05$ di tingkat kepercayaan 95\%. Berarti secara parsial, variabel usia dan tahap siklus hidup yang terdiri dari indikator remaja, umur tempat bergaul, dan semua kalangan usia berpengaruh signifikan terhadap keputusan konsumen berkunjung ke Nextdoor Cafe di Kota Palu.

Kesimpulan untuk hipotesis kedua dalam penelitian ini adalah menolak $\mathrm{H}_{0}$ dan menerima $\mathrm{H}_{\mathrm{i}}$. Artinya hipotesis kedua penelitian secara ilmiah dapat dibuktikan kebenarannya. Hal tersebut dapat dilihat dari total nilai mean indikator-indikator mengenai tanggapan responden berdasarkan usia dan tahap siklus hidup yang menunjukkan nilai di atas rata-rata sebesar 3,74.

Hal ini sejalan dengan penelitian yang dilakukan oleh Wahyuni (2016), yang menyatakan bahwa variabel usia $\left(\mathrm{X}_{1}\right)$ secara parsial berpengaruh terhadap keputusan pembelian.

\section{Pengaruh Pekerjaan terhadap Keputusan Konsumen}

Berdasarkan Tabel 2, dapat dilihat nilai koefisien regresi varibel pekerjaan $\left(\mathrm{X}_{2}\right)$ sebesar 0,048. Dapat diartikan bahwa pekerjaan memberikan hubungan positif pada keputusan konsumen berkunjung ke Nextdoor Cafe di Kota Palu, dengan nilai koefisien regresi sebesar 0,048. Hal ini memberi makna kontribusi pekerjaan $\left(\mathrm{X}_{2}\right)$ terhadap keputusan konsumen berkunjung ke Nextdoor Cafe di Kota Palu sebesar 4,8\%.

Pengujian hipotesis secara parsial diperoleh nilai $t_{\text {hitung }}$ pekerjaan $\left(\mathrm{X}_{2}\right)$ sebesar 2,346 > (lebih dari) nilai $t_{\text {tabel }}$ sebesar 2,004 atau nilai probabilitinya sebesar $0,031<$ (kurang dari) nilai $\alpha=0,05$ di tingkat kepercayaan 95\%. Berarti secara parsial, pekerjaan yang terdiri dari indikator tingkat 
pendapatan, status pekerjaan, dan masih tanggungan orang tua berpengaruh signifikan terhadap keputusan konsumen berkunjung ke Nextdoor Cafe di Kota Palu.

Kesimpulan untuk hipotesis ketiga dalam penelitian ini adalah menolak $\mathrm{H}_{0}$ dan menerima $\mathrm{H}_{\mathrm{i}}$. Artinya hipotesis ketiga penelitian secara ilmiah dapat dibuktikan kebenarannya. Hal tersebut dapat dilihat dari total nilai mean indikator-indikator mengenai tanggapan responden berdasarkan pekerjaan yang menunjukkan nilai di atas rata-rata sebesar 3,67.

Hal ini sejalan dengan penelitian yang dilakukan oleh Fauzi, et. al (2017) yang menyatakan bahwa ketiga variabel bebas yang salah satunya adalah faktor pribadi berpengaruh simultan, parsial dan signifikan terhadap keputusan pembelian, dan variabel dominannya adalah faktor pribadi yang di dalamnya meliputi pekerjaan.

\section{Pengaruh Gaya Hidup terhadap Keputusan Konsumen}

Berdasarkan Tabel 2, dapat dilihat nilai koefisien regresi varibel gaya hidup $\left(\mathrm{X}_{3}\right)$ sebesar 0,445. Dapat diartikan bahwa gaya hidup memberikan hubungan positif pada keputusan konsumen berkunjung ke Nextdoor Cafe di Kota Palu, dengan nilai koefisien regresi sebesar 0,445 . Hal ini memberi makna kontribusi gaya hidup $\left(\mathrm{X}_{3}\right)$ terhadap keputusan konsumen berkunjung ke Nextdoor Cafe di Kota Palu sebesar 44,5\%.

Pengujian hipotesis secara parsial diperoleh nilai $t_{\text {hitung }}$ gaya hidup $\left(X_{3}\right)$ sebesar 2,198 > (lebih dari) nilai $t_{\text {tabel }}$ sebesar 2,004 atau nilai probabilitinya sebesar 0,032 < (kurang dari) nilai $\alpha=0,05$ di tingkat kepercayaan 95\%. Berarti secara parsial, gaya hidup yang terdiri dari indikator aktifitas, minat dan opini berpengaruh signifikan terhadap keputusan konsumen berkunjung ke Nextdoor Cafe di Kota Palu.

Kesimpulan untuk hipotesis keempat dalam penelitian ini adalah menolak $\mathrm{H}_{0}$ dan menerima $\mathrm{H}_{\mathrm{i}}$. Artinya hipotesis keempat penelitian secara ilmiah dapat dibuktikan kebenarannya. Hal tersebut dapat dilihat dari total nilai mean indikator-indikator mengenai tanggapan responden berdasarkan gaya hidup yang menunjukkan nilai lebih tinggi dibanding variabel lainnya yaitu sebesar 4,44..Dengan demikian, variabel gaya hidup adalah yang paling dominan dalam faktor pribadi.

Hal ini sejalan dengan penelitian yang dilakukan oleh Fauzi, et. al (2017) yang menyatakan bahwa ketiga variabel bebas berpengaruh simultan, parsial dan signifikan terhadap keputusan pembelian, dan variabel dominannya adalah faktor pribadi yang di dalamnya meliputi gaya hidup.

\section{Pengaruh Keadaan Ekonomi terhadap Keputusan Konsumen}

Berdasarkan Tabel 2, dapat dilihat nilai koefisien regresi varibel keadaan ekonomi $\left(\mathrm{X}_{4}\right)$ sebesar 0,188. Dapat diartikan bahwa keadaan ekonomi memberikan hubungan positif pada keputusan konsumen berkunjung ke Nextdoor Cafe di Kota Palu, dengan nilai koefisien regresi sebesar 0,188 . Hal ini memberi makna kontribusi keadaan ekonomi $\left(\mathrm{X}_{4}\right)$ terhadap keputusan konsumen berkunjung ke Nextdoor Cafe di Kota Palu sebesar 18,8\%.

Pengujian hipotesis secara parsial diperoleh nilai $t_{\text {hitung }}$ keadaan ekonomi $\left(\mathrm{X}_{4}\right)$ sebesar 2,227 > (lebih dari) nilai $t_{\text {tabel }}$ sebesar 2,004 atau nilai probabilitinya sebesar 0,025 < (kurang dari) nilai $\alpha$ $=0,05$ di tingkat kepercayaan 95\%. Berarti secara parsial, keadaan ekonomi yang terdiri dari indikator harganya murah, sesuai keadaan ekonomi, dan kebutuhan berpengaruh signifikan terhadap keputusan konsumen berkunjung ke Nextdoor Cafe di Kota Palu.

Kesimpulan untuk hipotesis kelima dalam penelitian ini adalah menolak $\mathrm{H}_{0}$ dan menerima $\mathrm{H}_{\mathrm{i}}$. Artinya hipotesis kelima penelitian secara ilmiah dapat dibuktikan kebenarannya. Hal tersebut dapat dilihat dari total nilai mean indikator-indikator mengenai tanggapan responden berdasarkan keadaan ekonomi yang menunjukkan nilai di atas rata-rata sebesar 4,10. 
Hal ini sejalan dengan penelitian yang dilakukan oleh Jariah (2012) yang menyatakan bahwa variabel situasi ekonomi mempunyai pengaruh positif atau searah terhadap keputusan pembelian sepeda motor Yamaha.

\section{Pengaruh Kepribadian dan Konsep Diri terhadap Keputusan Konsumen}

Berdasarkan Tabel 2, dapat dilihat nilai koefisien regresi varibel kepribadian dan konsep diri $\left(\mathrm{X}_{5}\right)$ sebesar 0,201. Dapat diartikan bahwa kepribadian dan konsep diri memberikan hubungan positif pada keputusan konsumen berkunjung ke Nextdoor Cafe di Kota Palu, dengan nilai koefisien regresi sebesar 0,201. Hal ini memberi makna kontribusi kepribadian dan konsep diri (X) terhadap keputusan konsumen berkunjung ke Nextdoor Cafe di Kota Palu sebesar 20,1\%.

Pengujian hipotesis secara parsial diperoleh nilai $\mathrm{t}_{\text {hitung }}$ kepribadian dan konsep diri $\left(\mathrm{X}_{5}\right)$ sebesar 2,255 > (lebih dari) nilai $t_{\text {tabel }}$ sebesar 2,004 atau nilai probabilitinya sebesar 0,015 < (kurang dari) nilai $\alpha=0,05$ di tingkat kepercayaan 95\%. Berarti secara parsial, kepribadian dan konsep diri yang terdiri dari indikator kepercayaan diri, merasa puas, dan tradisi dalam keluarga berpengaruh signifikan terhadap keputusan konsumen berkunjung ke Nextdoor Cafe di Kota Palu.

Kesimpulan untuk hipotesis keenam dalam penelitian ini adalah menolak $\mathrm{H}_{0}$ dan menerima $\mathrm{H}_{\mathrm{i}}$. Artinya hipotesis keenam penelitian secara ilmiah dapat dibuktikan kebenarannya. Hal tersebut dapat dilihat dari total nilai mean indikator-indikator mengenai tanggapan responden berdasarkan kepribadian dan konsep diri yang menunjukkan nilai di atas rata-rata sebesar 4,01.

Hal ini sejalan dengan penelitian yang dilakukan oleh Hakimi (2015) yang menyatakan bahwa faktor pribadi berpengaruh terhadap keputusan pembelian konsumen di KFC Singaraja.

\section{KESIMPULAN DAN SARAN}

\section{Kesimpulan}

Berdasarkan hasil dan pembahasan yang telah dijabarkan, maka diperoleh kesimpulan mengenai pengaruh faktor pribadi terhadap keputusan konsumen berkunjung ke Nextdoor Cafe di Kota Palu adalah sebagai berikut :

1. Faktor pribadi yang terdiri dari usia dan tahap siklus hidup, pekerjaan, gaya hidup, keadaan ekonomi, serta kepribadian dan konsep diri secara serempak berpengaruh signifikan terhadap keputusan konsumen berkunjung ke Nextdoor Cafe di Kota Palu.

2. Usia dan tahap siklus hidup mempunyai pengaruh signifikan terhadap keputusan konsumen berkunjung ke Nextdoor Cafe di Kota Palu.

3. Pekerjaan mempunyai pengaruh signifikan terhadap keputusan konsumen berkunjung ke Nextdoor Cafe di Kota Palu.

4. Gaya Hidup mempunyai pengaruh signifikan terhadap keputusan konsumen berkunjung ke Nextdoor Cafe di Kota Palu.

5. Keadaan Ekonomi mempunyai pengaruh signifikan terhadap keputusan konsumen berkunjung ke Nextdoor Cafe di Kota Palu.

6. Kepribadian dan Konsep Diri mempunyai pengaruh signifikan terhadap keputusan konsumen berkunjung ke Nextdoor Cafe di Kota Palu.

\section{Saran}

Berdasarkan kesimpulan yang telah diuraikan sebelumnya, maka saran-saran yang tepat menyangkut kegunaan penelitian ini adalah sebagai berikut:

1. Disarankan agar membuat tempat atau menu sesuai dengan usia dan siklus hidup konsumennya. Misalnya, membuat ruangan berbeda untuk konsumen yang datang bersama keluarganya. 
2. Disarankan agar lebih menyesuaikan dan mengerti terhadap status pekerjaan konsumen. Misalnya dengan menyediakan ruangan berbeda untuk para pelajar yang berkunjung. Sehingga para pelajar tersebut tidak merasa canggung terhadap konsumen lain lebih tua dari mereka atau konsumen yang sudah bekerja.

3. Disarankan agar pengelola cafe berperan aktif dalam meningkatkan pelayanan konsumen.

4. Disarakan agar selalu melakukan analisis pasar, sehingga dengan demikian penetapan harga produk Nextdoor Cafe sesuai dengan target konsumen atau keadaan ekonomi target pasar.

5. Disarankan agar produk-produk makanan atau minuman yang di tawarkan di cafe ini dapat menciptakan image kebersamaan dan kenyamanan seperti dalam keluarga.

6. Disarankan agar pengelola cafe dapat mengembangkan dan melakukan berbagai inovasi terhadap menu yang disediakan dengan tetap menjaga cita rasanya.

7. Diharapkan hasil penelitian ini dapat dijadikan sebagai salah satu bahan referensi pada penelitian selanjutnya yang ingin mengadakan riset serupa dengan penelitian penulis agar menemukan kesempurnaan secara lebih ilmiah riset tentang faktor pribadi terhadap keputusan konsumen pada sebuah produk maupun jasa.

\section{REFERENSI}

Abdullah, Thamrin dan Francis Tantri. (2014). Manajemen Pemasaran. PT. Raja Grafindo Persada: Jakarta

Amelia, Yanis. (2013). Pengaruh Faktor Pribadi Terhadap Keputusan Konsumen Menggunakan Produk Samsung Galaxy Tab Di Kota Palu. Skripsi: Universitas Tadulako

Assauri, Sofjan. (2013). Manajemen Pemasaran. Jakarta : Rajawali Pers

Fauzi, Prasetya Arif, Nurul Qomari, Bramastyo Kusumo Negoro. (2017). Pengaruh Faktor Sosial, Pribadi Dan Psikologis Terhadap Keputusan Pembelian Produk Minuman Kukubima Ener-G Di Ud. Bangun Jaya Food Sidoarjo. Jurnal Manajemen Branchmark Vol 3 Issue 3, Hal. 308322

Ferdinand, Augusty. (2014). Metode Penelitian Manajemen. BP Universitas Diponegoro. Semarang Ferrinadewi, Erna. (2005). Pengaruh Tipe Keterlibatan Konsumen Terhadap Kepercayaan Merek dan Dampaknya Pada keputusan Pembelian: Jakarta

Ghozali, Imam. (2013). Aplikasi Analisis Multivariate dengan Program IBM SPSS 21. Edisi 7. Semarang. Badan Penerbit Universitas Diponegoro

Hakimi, Hendi. (2015). Pengaruh Faktor Pribadi Dan Faktor Psikologis Terhadap Keputusan Pembelian Konsumen Di Kentucky Fried Chicken Singaraja. Jurnal Vol: 5 No: 1, Hal. 4-9

Jariah, Ainun. (2012). Analisis Faktor-Faktor Pribadi Yang Mempengaruhi Keputusan Pembelian Sepeda Motor Yamaha Di Lumajang. Jurnal WIGA Vol. 2 No. 2, September, ISSN NO 20880944, Hal. 3-16

Towoliu, Juli E.S dan Willem. J.F.A Tumbuan. (2017). Pengaruh Faktor Pribadi Dan Faktor Keluarga Terhadap Keputusan Pembelian Di Rumah Makan Waroeng Tepi Laut, Manado. Jurnal EMBA Vol.5 No.2 Juni 2017, Hal. 308-322

Kotler, Philip and Kevin Lane Keller. (2016). Marketing Management Fifteenth Global Edition. Pearson Education: England

Kotler, Philip and Gary Amstrong. (2013). Principle Of Marketing, Fourteenth Edition. Pearson Education: England

Roscoe. (1982). Research Methods For Business. New York. Mc Graw Hill

Sugiyono. (2016). Metode Penelitian Manajemen (Pendekatan Kuantitatif, Kualitatif dan R and D). Bandung: Alfabeta

Suliyanto. (2011). Ekonometrika Terapan: Teori dan Aplikasi dengan SPSS. Penerbit Andi . Yogyakarta 


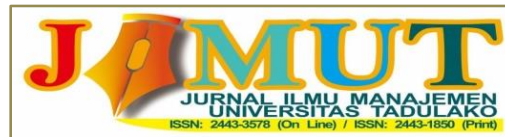

Vol. 6, No.3, September 2020, 261-271

Sunyoto, Danang. (2015). Perilaku Konsumen dan Pemasaran. Yogyakarta : CAPS

Suprayanto \& Rosad. (2015). Manajemen Pemasaran. IN MEDIA: Bogor

Swastha, Basu \& Irawan. (2008). Menejemen Pemasaran Modern. Cetakan Ketujuh. Penerbit LIBERTY:Yogyakarta

Wahyuni. (2016). Pengaruh Faktor-Faktor Pribadi Terhadap Keputusan Pembelian Produk Indihome pada PT Telkom, Tbk Witel di kota Samarinda. eJournal Ilmu Administrasi Bisnis, 4 (2) Hal. 565-574 